Mieczysława Zdanowicz

\title{
READMISJA W RELACJACH POLSKI I ROSJI
}

\section{Uwagi wstepne}

Polska wraz ze wstapieniem do Unii Europejskiej przekazała na rzecz tej organizacji część swoich kompetencji. Dotyczy to m.in. spraw związanych z granicami państwa, w tym zasadami ich przekraczania. Pierwszy etap związanych z tym przemian obejmował harmonizację zasad polityki wizowej, drugi zaś wiązał się z pełnym wdrożeniem acquis Schengen.

Kluczowe znaczenie dla rozwijania współpracy z państwami sąsiednimi, które nie są państwami członkowskimi UE i nie są z nią stowarzyszone, ma znalezienie $\mathrm{z}$ jednej strony zasad liberalizacji reżimu wizowego, z drugiej zaś - wzmocnienie wspólnych działań w celu zwalczania nielegalnej imigracji.

Działania Unii Europejskiej pokazują, że szuka ona właściwego balansu między bezpieczeństwem wewnętrznym a stabilizacją zewnętrzną. Powiązanie umów o ułatwieniach wizowych z readmisyjnymi jest standardowym instrumentem w Europejskiej Polityce Dobrego Sąsiedztwa. ${ }^{1}$ Umowa o readmisji i umowa o ułatwieniach wizowych zostały też przyjęte między Unią Europejską a Rosją. Umowa o ułatwieniach wizowych nie wpłynęła na wzrost liczby obywateli FR przekraczających granicę z Polską ${ }^{2}$. Czy zatem umowa o readmisji może być skutecznym instrumentem zwalczania nielegalnych wjazdów i pobytów w dwustronnych relacjach Polski i Rosji?

Readmisja oznacza przekazanie przez państwo składające wniosek i przyjęcie przez państwo rozpatrujące wniosek osób (własnych obywateli państwa rozpatrują-

1 F. Trauner, I. Kruse, EC Visa Facilitation and Readmission Agree 4 ments, A New Standard EU Foreign Policy Tool?, „European Journal of Migration and Law” 2008, nr 10, s. 434-435.

2 M. Zdanowicz, A. Doliwa-Klepacka, Możliwość liberalizacji reżimu wizowego w ramach Współpracy państw w Partnerstwie Wschodnim, (w:) M. Zdanowicz, T. Dubowski, A. Piekutowska, Partnerstwo Wschodnie. Wymiary realnej integracji, Warszawa 2010, s. 163. 
cego wniosek, obywateli państw trzecich lub bezpaństwowców), którym udowodniono nielegalny wjazd, nielegalny pobyt lub nielegalne zamieszkiwanie na terytorium państwa wnioskodawcy. ${ }^{3}$

Readmisja ma na celu ułatwienie powrotu/przyjęcia osób przebywających na terytorium danego państwa bez wymaganych dokumentów. Umowy readmisyjne są to umowy (zwykle bilateralne), które odnoszą się do procedur odesłania przez jedno państwo cudzoziemca przebywającego na jego terytorium bez wymaganych dokumentów do państwa jego obywatelstwa lub państwa, przez które przejechał on do państwa, które podejmuje kroki do jego odesłania ${ }^{4}$. Zdaniem D. Bouteillet-Paquet umowy readmisyjne są aktualnie jednym z najstarszych instrumentów stosowania przez państwa członkowskie kontroli napływu migrantów ${ }^{5}$.

Pierwsza generacja umów readmisyjnych była przyjęta w latach 50-tych i 60tych i obejmowała osoby nieprawidłowo przemieszczające się miedzy państwami członkowskimi tworzącymi później strefę Schengen. Ta polityka była uzewnętrzniana w drugiej generacji bilateralnych umów readmisyjnych zawieranych z państwami Europy Środkowo-Wschodniej. ${ }^{6}$ Umowy te miały zapobiegać nielegalnej i niekontrolowanej migracji po upadku „muru berlińskiego”. Wówczas to szereg państw europejskich podjęło starania o współpracę z państwami członkowskimi.

Dnia 30 listopada 1994 roku Rada przyjęła Rekomendacje ${ }^{7}$, w których wzywała państwa członkowskie do zawierania z państwami trzecimi standardowych umów o readmisji. Ich celem miało być zwalczanie nielegalnej imigracji. Standardowa umowa określała osoby objęte readmisją, terminy, w ciągu których zainteresowane państwo zobowiązane jest do określonych działań, zasady tranzytu, ochrony danych osobowych oraz pokrycia kosztów takich operacji (działań). W. Czapliński zauważa, iż pierwowzorem takich umów było porozumienie między państwami grupy Schengen a Polską, zawarte 29 marca 1991 roku. Na podstawie tego porozumienia wprowadzono ruch bezwizowy między państwami stronami. ${ }^{8}$

3 Ta legalne definicja ekstradycji znajduje sie w niektórych umowach międzynarodowych, o czym będzie szerzej w dalszej części niniejszego rozdziału.

4 P.J. van Krieken, The Migration Acquis Handbook. The Foundation for a Common European Migration Policy, Haga 2001, s. 425-426.

5 D. Bouteillet-Paquet, Passing the Buck, a critical analysis of the readmission policy implemented by the European Union and its Member States', „European Journal of Migration and Law” 2003, nr 5, s. 359-377; za A. Roig, T. Huddleston, EC Readmission Agreements, A Re-evaluation of the Political Impasse, „European Journal of Migration and Law" 2007, nr 9, s. 367.

6 A. Roig, T. Huddleston, EC Readmission Agreements, A Re-evaluation of the Political Impasse, „European Journal of Migration and Law" 2007, nr 9, s. 376.

7 Council Recommendation of 30 November 1994 concerning a specimen bilateral readmission agreement between a Member State and a third country, „Official Journal” C 274 , 19/09/1996 P. 0020-0024.

8 W. Czapliński, C. Mik, Traktat o Unii Europejskiej. Komentarz, Warszawa 2005, s. 4. Konwencje międzynarodowe zawierane na podstawie art. K.3. 
Dnia 24 lipca 1995 roku Rada przyjęła Rekomendacje ${ }^{9}$ w sprawie zasad, które powinny być brane pod uwagę przy sporządzaniu protokołów wykonawczych do umów o readmisji. Rada zalecała przyjęcie wspólnych formularzy, zasad powrotu/readmisji w przypadku zastosowania procedury uproszczonej i zwykłej, sposobu identyfikacji osoby, która podlega readmisji oraz środki dowodowe, na podstawie których stwierdzono wjazd takiej osoby. Określono ponadto warunki tranzytu.

Następnie Komitet Wykonawczy Schengen w dniu 15 grudnia 1999 roku przyjął decyzję dotyczącą dowodów, które mają być brane pod uwagę przy realizacji umów o readmisji pomiędzy państwami Schengen. Drugiego grudnia 1997 roku Rada podjęła decyzję dotyczącą klauzul readmisyjnych ${ }^{10}$. Po wejściu w życie Traktatu Amsterdamskiego klauzule te były stosowane we wszystkich umowach zawieranych przez państwa członkowskie UE. Kilka dni później, 7 grudnia, Finlandia przedstawiła propozycję objęcia readmisją także obywateli państw trzecich. ${ }^{11}$ Zgodnie ze stanowiskiem Finlandii obywatelem państwa trzeciego jest osoba niebędąca obywatelem państwa członkowskiego UE ${ }^{12}$. Rada Europejska na szczycie w Tampere w październiku 1999 roku potwierdziła, iż Traktat Amsterdamski przyznał Wspólnocie kompetencje w dziedzinie readmisji. Rada Europejska zaleciła Radzie UE zawieranie umów o readmisji lub włączanie standardowych klauzul do innych umów zawieranych między Wspólnotą Europejską a poszczególnymi krajami lub grupami krajów trzecich. Potrzebę zawierania takich umów powtórzono także na posiedzeniu Rady Europejskiej w Laeken. W 2002 roku Rada określiła następujące kryteria wpływające na zawarcie umów o readmisji: 1) presja migracyjna wywierana przez państwo trzecie; 2) geograficzne położenie państwa w stosunku do UE; 3) fakt, że państwo nie kandyduje do UE; 4) rozważenie geograficznego balansu i regionalnych konsekwencji; 5) istnienie umów o stowarzyszeniu z UE czy umów o współpracy zawierających klauzule readmisyjne; 6) dodatkowe wartości, jakie wynikają z umowy wspólnoty w porównaniu z umowami zawieranymi przez poszczególne państwa członkowskie ${ }^{13}$. Aktualnie art. 79 ust. 3 TfUE przyznaje Unii prawo do zawierania z państwami trzecimi umów o readmisji do państwa pochodzenia lub państw, z któ-

9 Council Recommendation of 24 July 1995 on the guiding principles to be followed in drawing up protocols on the implementation of readmission agreements, „Official Journal” C 274, 19/09/1996 P. 0025-0033.

10 Pierwsze klauzule readmisyjne znalazły się już w Umowach o Partnerstwie i Współpracy podpisanych w 1995 roku z Kazachstanem i Kirgistanem czy w 1996 z Armenia, Gruzją i Uzbekistanem. Kolejne umowy zawarte były z Algeria, Azerbejdżanem, Chile, Chorwacja, Egiptem, Libanem, Macedonia, Syrią i Turkmenistanem. Unia włączała także takie klauzule do umów z regionalnymi organizacjami, za A. Roig, T. Huddleston, EC Readmission Agreements, A Re-evaluation of the Political Impasse, "European Journal of Migration and Law" 2007, nr 9, s. 370 .

11 Informacje pochodzą ze strony, http://europa.eu/legislation_summaries/other/l33105_en.htm .(dnia 21 lipca 2010 roku).

12 Council Initiative of the Republic of Finland with a view to the adoption of a Council Regulation determiningobligations as between the Member States for the readmission of third-country nationals, „Official Journal” C 353, 7.12.1999 P. 0007-0009.

13 M. Schieffer, Community Readmission Agreements with Third Countries - Objectives, Substance and Current State of Negotiations, „European Journal of Migration and Law” 2003, nr 5, s. 347-348. 
rych przybywają, obywateli państw trzecich, którzy nie spełniają warunków wjazdu, obecności lub pobytu na terytorium jednego z państw członkowskich lub przestali je spełniać ${ }^{14}$.

\section{II}

Stosunki Rosji z Unią Europejską zostały po raz pierwszy sformalizowane w 1994 roku, kiedy to podpisano układ o partnerstwie i współpracy. W wyniku tego porozumienia rozwinął się dialog polityczny, przejawem czego stały się spotkania na szczycie. Jednym z działań zaproponowanych w przyjętej w dniu 4 lipca 1999 r. wspólnej strategii UE wobec Rosji było zawarcie umowy w sprawie readmisji.

W dniu 18 września 2000 r. Rada ds. Ogólnych upoważniła Komisję do podjęcia negocjacji dotyczących umowy o readmisji między Wspólnotą Europejską i Federacją Rosyjską. W kwietniu 2001 r. Komisja przekazała władzom rosyjskim projekt tekstu umowy. Rozpoczęły się długie negocjacje.

Problem ten był również przedmiotem dyskusji na spotkania na szczycie, które miało miejsce dnia 31 maja 2003 roku w Sankt Petersburgu, podczas obchodów 300-lecia tego miasta. Ustanowiono na nim 4 wspólne przestrzenie wzajemnej współpracy: gospodarcza; wolności, sprawiedliwości i bezpieczeństwa; bezpieczeństwa międzynarodowego; i badań naukowych, edukacji i kultury. Podkreślając potrzebę współpracy w dziedzinie wymiaru sprawiedliwości i spraw wewnętrznych, Unia Europejska i Rosja uznały za pożądane wprowadzenie w dalszej perspektywie ruchu bezwizowego oraz wskazano na potrzebę bardziej elastycznego podejścia do przepisów Porozumień z Schengen. Podnoszono również problem umów o readmisji, jednak nie udało się uzyskać od Rosji żadnych konkretnych zobowiązań. ${ }^{15}$ Podpisanie umowy nastapiło dopiero w roku $2006^{16}$. Umowa weszła w życie dnia 19 kwietnia 2007 roku.

Komisja podkreślała, iż brak zachęt ze strony UE był przyczyną przedłużających się negocjacji. I tak naprawdę przyspieszyły dopiero wtedy, gdy UE zobowiązała się, na wniosek FR, do jednoczesnego negocjowania umów o ułatwieniach wizowych. ${ }^{17}$

\footnotetext{
14 Wersja skonsolidowana Traktatu o Funkcjonowaniu Unii Europejskiej podpisanego 13 grudnia 2007 roku, „Dziennik Urzędowy UE" 2008, C 115/47.

15 E. Wyciszkiewicz, Szczyt Unia Europejska - Federacja Rosyjska (Sankt-Petersburg, 31 maja 2003), Polski Instytut Spraw Międzynarodowych. Biuro Analiz, Biuletyn 2003, Nr 31, s. 830.

16 Umowa o readmisji między Federacją Rosyjską a Wspólnotą Europejską, podpisana w 2006 roku, Dz.U. UE L 2007.129.40.

17 Komunikat Komisji do Parlamentu Europejskiego I Rady. Ocena unijnych umów o readmisji, KOM(2011) 76 wersja ostateczna.
} 


\section{III}

W preambule Umowy o readmisji między Federacją Rosyjską a Wspólnotą Europejską podkreślono, iż celem tych umów jest skuteczniejsze zwalczanie nielegalnej imigracji. Wskazano ponadto na potrzebę ustanowienia, na zasadzie wzajemności i w duchu współpracy, szybkiej i skutecznej procedury ustalania tożsamości i organizowania bezpiecznego i zgodnego z przepisami powrotu osób, które nie spełniają warunków wjazdu, przebywania lub pobytu na terytorium państw stron lub przestały spełniać te warunki. Państwa pragną także ułatwić tranzyt takich osób. Wsazano ponadto, iż umowa nie narusza praw, obowiqzków i zakresu odpowiedzialności Wspólnoty, państw członkowskich Unii Europejskiej i Federacji Rosyjskiej wynikajacych z prawa międzynarodowego, $w$ tym przepisów $w$ zakresie międzynarodowych praw czlowieka, potwierdzonych w szczególności w Powszechnej deklaracji praw człowieka z dnia 10 grudnia 1948 r., Międzynarodowym pakcie praw obywatelskich i politycznych z dnia 16 grudnia 1966 r., Konwencji dotyczqcej statusu uchodźców z dnia 28 lipca 1951 r. i Protokole dotyczacym statusu uchodźców z dnia 31 stycznia 1967 r., Europejskiej konwencji o ochronie praw czlowieka i podstawowych wolności z dnia 4 listopada $1950 \mathrm{r}$. i protokole $\mathrm{nr} 4$ do tejże konwencji z dnia 16 września 1963 r. oraz Konwencji w sprawie zakazu stosowania tortur oraz innego okrutnego, nieludzkiego lub poniżajacego traktowania albo karania z dnia 10 grudnia $1984 \mathrm{r}$.

W zasadzie postanowienia zawarte we wstępie umowy międzynarodowej nie mają charakteru prawnie wiążącego, nie tworzą praw i zobowiązań dla stron, są jednak ważnym elementem przy rozstrzyganiu problemów interpretacyjnych, zwłaszcza w tak delikatnej sferze jak przejęcie nielegalnie przebywających osób.

We wstępie umowy o readmisji mamy też określony zakres jej stosowania. Podkreślono, iż porozumienie to nie ma zastosowania do Królestwa Danii (zgodnie z protokołem złożonym przez to państwo do Traktatu o Unii Europejskiej i Traktatu ustanawiającego Wspólnotę Europejską).

Postanowienia merytoryczne rozpoczynają się od zdefiniowania podstawowych pojęć, takich jak np.: państwo członkowskie, obywatel państwa członkowskiego, obywatel państwa, które jest stroną porozumienia, bezpaństwowiec, wiza, zezwolenie na zamieszkanie, rejon przygraniczny lub dokument pobytowy.

Umowa określa obowiązki stron w zakresie readmisji, procedurę, tranzyt i koszty, ochronę danych i klauzulę braku wpływu oraz zasady wejścia wżycie i stosowania umowy.

Pierwsza część umowy określa obowiązki państw stron w zakresie readmisji. Federacja Rosyjska zobowiązuje się, na wniosek państwa członkowskiego i zgodnie z procedurą przewidzianą w umowie, przyjąć obywateli FR, którzy nie spełnia- 
ją obowiązujących warunków wjazdu, pobytu lub zamieszkiwania na terytorium państwa członkowskiego wnioskodawcy. To samo odnosi się do osób nielegalnie przebywających lub zamieszkujących na terytorium państwa członkowskiego, które w chwili wjazdu na to terytorium posiadały obywatelstwo Federacji Rosyjskiej, następnie zaś zrzekły się go zgodnie z prawem rosyjskim, nie uzyskując obywatelstwa ani zezwolenia na pobyt w państwie, do którego przybyły, ani w żadnym innym państwie. ${ }^{18}$ Ta sama zasada odnosi się również do cudzoziemców, jeżeli istnieją dowody na to, iż taka osoba:

a) posiada w chwili składania wniosku o readmisję ważną wizę wydaną przez Federację Rosyjską i upoważniająca ją do wjazdu na terytorium państwa członkowskiego bezpośrednio z terytorium Federacji Rosyjskiej; lub

b) posiada w chwili składania wniosku o readmisję ważne zezwolenie na pobyt wydane przez Federację Rosyjską; lub

c) wjechała bezprawnie na terytorium państwa członkowskiego bezpośrednio $\mathrm{z}$ terytorium Federacji Rosyjskiej. ${ }^{19}$

Należy jednak podkreślić, iż zgodnie $\mathrm{z}$ art. 23 ust. 3 umowy postanowienia zawarte w art. 3-5 mają wyłącznie zastosowania do bezpaństwowców i obywateli państw trzecich, z którymi Federacja Rosyjska zawarła dwustronne umowy o readmisji. W stosunku do pozostałych cudzoziemców zaczęła mieć zastosowanie dopiero po upływie trzech lat od daty wejścia jej w życie.

Obowiązek readmisji nie ma zastosowania, gdy:

a) obywatel państwa trzeciego lub bezpaństwowiec przebywa na terenie międzynarodowego portu lotniczego w Federacji Rosyjskiej jedynie przejazdem w ramach tranzytu lotniczego; lub

b) państwo członkowskie wnioskodawca lub inne państwo członkowskie wydało obywatelowi państwa trzeciego lub bezpaństwowcowi wizę lub zezwolenie na pobyt (o ile taka osoba nie jest już w posiadaniu wizy lub zezwolenia na pobyt wydanych przez Federację Rosyjską), które mają dłuższy okres ważności;

c) obywatel państwa trzeciego lub bezpaństwowiec korzystali z prawa bezwizowego wjazdu na terytorium państwa członkowskiego wnioskodawcy. ${ }^{20}$

Analogiczne zobowiązania zostały przyjęte przez państwa członkowskie UE (sekcja II). 
Jednak readmisja obywateli państw trzecich został odroczona na trzy lata (art. 23 ust. 3).

Państwa zobowiązały się do wydania osobom podlegającym readmisji dokumentów podróży wymaganych do powrotu.

Kolejna ważna część umów dotyczy procedury readmisji. Przekazanie osoby wymaga złożenia wniosku o readmisję do właściwego organu państwa rozpatrującego wniosek. Jednak wniosek nie jest konieczny, jeżeli osoba, która ma podlegać readmisji, posiada ważny paszport krajowy, a w przypadku obywatela państwa trzeciego lub bezpaństwowca jest także w posiadaniu ważnej wizy lub ważnego zezwolenia na pobyt wydanego w państwie, które ma taką osobę przyjąć na swoje terytorium. (art. 5 ust. 1 i 2 ).

Wspólny wzór formularza wniosku o readmisję stanowi załącznik do umowy.

Obywatelstwo można udowodnić za pomocą paszportu, zaświadczenia o powrocie do FR, krajowych dokumentów tożsamości państw członkowskich UE oraz wojskowych dokumentów tożsamości, książeczek żeglarskich i legitymacji służbowych kapitanów jednostek morskich, zaświadczeń o obywatelstwie lub innych urzędowych dokumentów, w którym wymieniono wyraźnie obywatelstwo (załącznik nr 2 do umowy).

Wniosek o readmisję składa się do właściwego organu państwa rozpatrującego wniosek w ciagu 180 dni kalendarzowych od daty uzyskania przez właściwy organ państwa składającego wniosek informacji, że obywatel państwa trzeciego lub bezpaństwowiec nie spełnia obowiązujących warunków wjazdu, przebywania lub pobytu bądź przestał spełniać takie warunki (art. 11 ust. 1). Odpowiedź na wniosek o readmisję jest udzielana na piśmie w terminie 25 dni kalendarzowych od daty potwierdzonego jego odbioru (art. 11 ust. 2). Umowa przewiduje przyspieszoną procedurę, jeżeli osobę zatrzymano w regionie przygranicznym. Wówczas państwo ma 2 dni na udzielenie odpowiedzi na wniosek (art. 11 ust. 3).

Odrzucenie wniosku o readmisję jest uzasadniane (art. 12).

Koszty związane z readmisją osoby ponosi strona składająca wniosek (art. 16).

Komisja (przy silnym poparciu państw członkowskich) podkreśla, że unijne umowy o readmisji są niezależnymi, bezpośrednio działającymi instrumentami. ${ }^{21}$ Ma to oczywiście swoje zalety w postaci usprawnienia postępowania, jednak niejednokrotnie rozwiązanie takie poddawane jest krytyce.

21 Komunikat Komisji do Parlamentu Europejskiego I Rady. Ocena unijnych umów o readmisji, KOM(2011) 76 wersja ostateczna. 
S. Zhenet ${ }^{22}$ oraz S. Kupriejew ${ }^{23}$ podkreślaja, iż procedura readmisji nie podlega kontroli organów sądowych. L. Andriczenko ${ }^{24}$ wskazuje, iż w procedurze tej uczestniczą organy administracyjne. Wyraża przy tym przekonanie, iż nie powinno to wpływać na realizację wobec osoby podlegającej readmisji praw człowieka.

Komisja wskazuje, iż Unia Europejska uznaje unijne umowy o readmisji za instrumenty techniczne umożliwiające wprowadzenie ulepszeń proceduralnych do współpracy między administracjami. Sytuacji osoby podlegającej readmisji dotychczas nie uregulowano, pozostawiając te kwestie właściwemu prawu międzynarodowemu, unijnemu oraz krajowemu. ${ }^{25}$

Umowa o readmisji zawarta między FR a WE zawiera zobowiązanie zawarcia protokołów wykonawczych (art. 20). Polska dotychczas nie zawarła takiego protokołu z FR.

Komisja oceniając stosowanie tych umów, zwraca uwagę na braki związane z przekazywaniem danych statystycznych, gdyż państwa wśród wydalonych cudzoziemców nie wyodrębniają grupy przekazanych na podstawie umowy readmisyjnej. ${ }^{26}$ Również dane statystyczne KG Straży Granicznej w Polsce nie zawierają takiego rozróżnienia, stąd też trudno ocenić, jak wygląda realizacja tej umowy w praktyce.

\section{Uwagi końcowe}

Umowy o readmisji nierozerwalnie związane są z jednej strony z liberalizacją polityki wizowej państw europejskich, z drugiej zaś z wyekzekwowaniem opuszczenia przez cudzoziemca terytorium państwa, gdy udowodniono mu nielegalny wjazd, pobyt lub nielegalne zamieszkiwanie. Uproszczona procedura, która ma zastosowanie w przypadku readmisji, jest poważnym atrybutem, aby ta instytucja mogła stać się efektywnym instrumentem regulującym pobyt cudzoziemców na terytorium danego państwa. Oceniając stosowanie umowy o readmisji w dwustronnych stosunkach Polski i Rosji, należy zwrócić uwagę na następujące sprawy:

1) w związku z wejściem Polski do UE i wprowadzeniem obowiązku wizowego wobec obywateli FR, następnie zaś w związku z związaniem się przez

С. ЭюЖенетль, Роль суда в миграционном процессе, Российский судья 2010, Нр. 11, Консультант Плюс С.С. Купреев, Меры административного принуждения, применямые к иностранным гражданам без гражданства за нарушение правил пребываниа в Российской Федерации, "Административное и муниципальное право" 2009, нр 10, Консультант Плюс.

4 Л.В. Андриченко, Проблемы роавового регулированиа реадмиссии, “Журнал российского права” 2010, нр 3, Консультант Плюс.

Komunikat Komisji do Parlamentu Europejskiego I Rady. Ocena unijnych umów o readmisji, KOM(2011) 76 wersja ostateczna, s. 11.

Komunikat Komisji do Parlamentu Europejskiego I Rady. Ocena unijnych umów o readmisji, KOM(2011) 76 wersja ostateczna, s. 3-4. 
Polskę dorobkiem Schengen odnotowuje się spadek liczby osób - obywateli obu państw - przekraczających granice Polski i Rosji;

2) wprowadzenie klauzuli dotyczącej obywateli państw trzecich, do których w okresie trzech lat umowa nie miała zastosowania, w znaczny sposób wpłynęło na ograniczenie jej stosowania.

Należy więc podkreślić, iż umowa o readmisji jest ważnym instrumentem dla zapewnienia skutecznego zarządzania przepływami migracyjnymi, zapewnia bowiem szybki powrót nielegalnych imigrantów. Dotychczas w relacjach Polski z FR nie była w pełni wykorzystanym środkiem. 


\section{РЕАДМИССИЯ В ОТНОШЕНИЯХ ПОЛЬШИ И РОССИИ}

Договоры о реадмиссии неразрывно связаны, с одной стороны, с либерализацией визовой политики европейских государств, а с другой - с необходимостью обеспечить выезд иностранца с территории государства, если доказан его незаконный въезд, пребывание или незаконное проживание в этом государстве. Упрощенная процедура, которая применяется в случае реадмиссии, является серьезным фактором, благодаря которому этот институт может стать эффективным инструментом, регулирующим пребывание иностранцев на территории того или иного государства. Оценивая применение договора о реадмиссии в двусторонних отношениях Польши и России, надо обратить внимание на следующие проблемы:

1) в связи со вступлением Польши в ЕС и введением визовых требований в отношении граждан РФ, а также в связи с использованием Польшей достижений Шенгена отмечается снижение количества лиц - граждан обоих государств, пересекающих границу Польши и России;

2) введение режима, касающегося граждан третьих государств, в отношении которых на протяжении трех лет договор не применялся, в значительной степени обусловило ограничение его применения.

Следует отметить, что договор о реадмиссии является важным инструментом эффективного регулирования миграционных потоков, так как он гарантирует быстрое возвращение незаконных иммигрантов. В отношениях Польши с РФ это средство до сих пор не используется в полной мере. 


\section{READMISSION IN POLISH-RUSSIAN RELATIONS}

Readmission agreements are inextricably linked on the one hand with the liberalization of visa policies of the European countries, and on the other hand, with the execution of an alien's departure from the territory of the state, when illegal entry, stay or illegal residence has been proven. The simplified procedure, which applies in the case of readmission, is the major attribute for its becoming an effective instrument regulating the stay of aliens in the territory of the state concerned. In assessing the application of a readmission agreement in the bilateral relations of Poland and Russia, attention should be paid to the following matters:

1) in connection with Poland's entry to the EU and the introduction of the visa requirement for citizens of the Russian Federation, with the consequent requirement that Poland should be bound by the Schengen acquis, a decrease in the number of persons - nationals of both countries - crossing the borders of Poland and Russia - was recorded;

2) the introduction of the clause regarding the nationals of third countries, to whom over a period of three years, the agreement was not applicable, significantly affected the restriction of its application.

It therefore should be stressed that while the agreement on readmission is an important instrument for ensuring the effective management of the flow of migration, it provides for the quick return of illegal immigrants. So far it has not been fully used as a measure in the relations between Poland and the Russian Federation.

Key words:

Readmission agreement, the Russian Federation, Poland, immigrants, illegal entry, stay, residence 